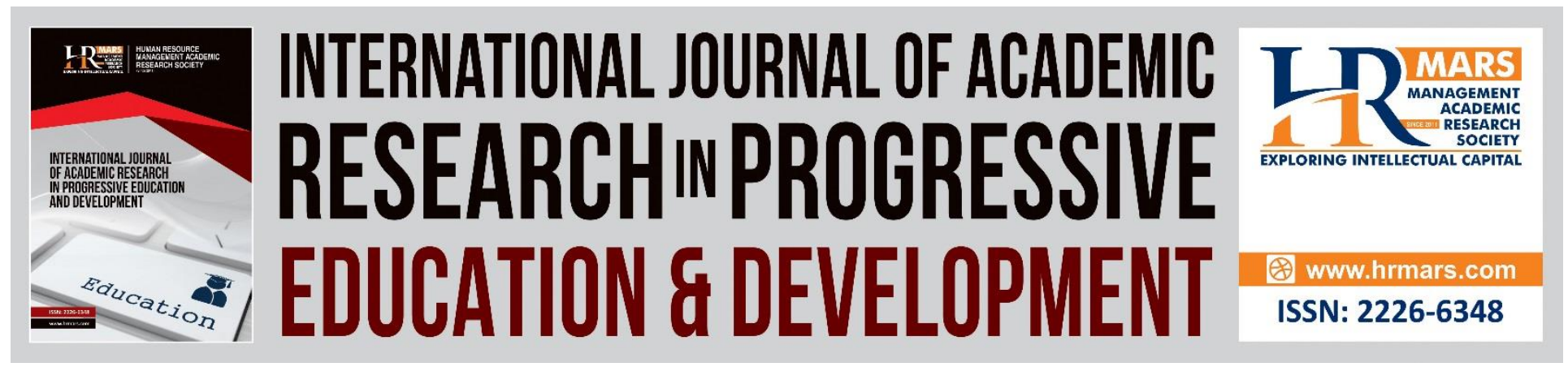

\title{
The Attitude and Motivation of Islamic Studies Students towards Learning the English Learning
}

Soh, Or-Kan, Noor Shafida Amiera Bt Mohd Sharif

To Link this Article: http://dx.doi.org/10.6007/IJARPED/v10-i2/10147

DOI:10.6007/IJARPED/v10-i2/10147

Received: 01 April 2021, Revised: 23 April 2021, Accepted: 19 May 2021

Published Online: 18 June 2021

In-Text Citation: (Soh \& Sharif, 2021)

To Cite this Article: Soh, O.-K., \& Sharif, N. S. A. B. M. (2021). The Attitude and Motivation of Islamic Studies Students towards Learning the English Learning. International Journal of Academic Research in Progressive Education and Development, 10(2), 625-647.

Copyright: (C) 2021 The Author(s)

Published by Human Resource Management Academic Research Society (www.hrmars.com)

This article is published under the Creative Commons Attribution (CC BY 4.0) license. Anyone may reproduce, distribute, translate and create derivative works of this article (for both commercial and non-commercial purposes), subject to full attribution to the original publication and authors. The full terms of this license may be seen

at: http://creativecommons.org/licences/by/4.0/legalcode

Vol. 10(2) 2021, Pg. 625 - 647

http://hrmars.com/index.php/pages/detail/IJARPED

JOURNAL HOMEPAGE

Full Terms \& Conditions of access and use can be found at http://hrmars.com/index.php/pages/detail/publication-ethics 


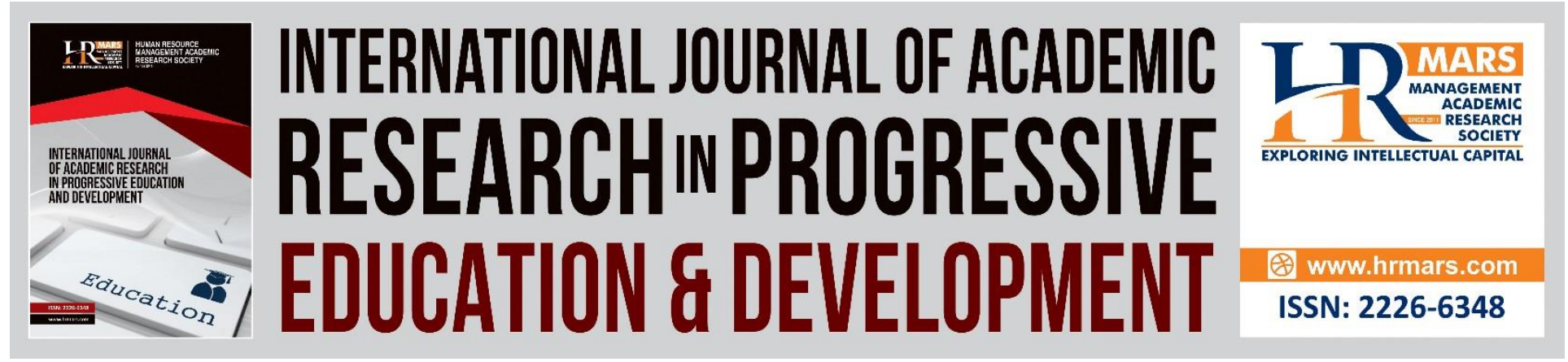

\title{
The Attitude and Motivation of Islamic Studies Students towards Learning the English Learning
}

\author{
Soh, Or-Kan, Noor Shafida Amiera Bt Mohd Sharif \\ Centre for Research in Language \& Linguistics, Faculty of Social Sciences \& Humanities, \\ Universiti Kebangsaan Malaysia (UKM) \\ Email:sok@ukm.edu.my
}

\begin{abstract}
The aim of this study is to shed lights on The Attitudes and Motivation in English Language Learning among the Islamic studies students in National University of Malaysia (UKM). Majority of the Malaysian students still have low proficiency level in English language consider that English language has been applied for more than ten years long in Malaysia education system. Plus, English is placed as the second language in Malaysia (Gill, 2002) and in line with the education policy; English is taught as a second language whereas in UKM, the Islamic studies students claimed that Arabic is their second language and English is a foreign language to them. The theory that govern this research is Behaviorist view by Skinner (1990), who noted that behaviorism is the way to measure attitudes and level of motivation. Ironically, despite having English as a foreign language to the students of Islamic studies, from the findings, it is presumed that generally the Islamic studies students have positive attitudes in English language learning, and they also intrinsically motivated towards English language learning.
\end{abstract}

Keywords: Attitude, Motivation, Islamic Studies Students, Learning, English Language

\section{Introduction}

The importance of English is undeniable nowadays and for that, English is considered as a second language in Malaysia since the colonial days and soon after Malaysia gained independence in 1957, the English language has played the role of the nation's official language among other races in Malaysia including Malays, Chinese, and Indians (Thang, Ting and Nurjanah, 2011). The importance of English is highly noted when English is placed as the second language in Malaysia (Gill, 2002) and in line with the education policy; English is taught as a second language. In contrast with Gill (2002) statements, according to Melor and Rashidah Khairunnisa, Ranjeeta (2011) had stated that the Islamic studies students speak Arabic as their second language and English is considered as a foreign language to them. On that note, the Islamic studies students in the Universiti Kebangsaan Malaysia (UKM), claimed that they speak Arabic as their second language and English is regarded as a foreign language to them. Despite the significant of the 
English language learning to Malaysian education system, little is known about the attitudes and motivation level in English language learning among the Islamic studies students as the Islamic studies students are often associated with Arabic language instead of English language (Abdullah et al, 2012). The aim of this study is to shed lights on the attitudes and motivation in English Language Learning among the Islamic studies students in Universiti Kebangsaan Malaysia (UKM). English language learning is closely related with motivation and attitudes of the speakers [4]. How the speakers perceived English is very important in order for them to be able to motivate themselves in the process of learning English. Studies have shown that Malaysian students are well aware of the importance of English for their future careers (Madziah and Isarji, 2009; Chalak and Kassaian, (2010); Seidlhofer (2004); Thao and Tham (2013)). These days, tertiary level students are mostly concern about their employments status once they graduated. Kaur (2014) highlighted the employers claimed that the Malaysian graduates have low English proficiency level. Therefore, the consequences are the difficulty to find a decent job among the fresh graduates in Malaysia and that is why English language learning is very crucial and vital for students among the tertiary level education to enroll despite whatever courses they major in as English language learning is imperative for their future careers. Additionally, students are extrinsically motivated by factors such as desire to get good grades, opportunities to further their studies and career advancement to improve their English. However, these studies also revealed that extrinsic motivation does not necessarily translate to better performance in English (Madziah and Isarji, 2009; Bidin et al., 2009; Abidin, Pour-Mohammadi, Alzwari, 2012; Yang, 2010).

Brown (2000) highlighted that motivation is simply an anticipation of rewards. He further defined the term motivation as the degree of effort the students exert in respect to the choices they make and what they aim for. On that note, Crossey (2008), explain that motivation is divided into intrinsic and extrinsic motivation. Intrinsic motivation is where the students learn English for his or her own goal. Meanwhile, extrinsic motivation is when the students learn for the sake of reward and punishment. Gardner (1980) defined attitude as an interpretation made from the basis of a complex of beliefs about the attitude projected by an individual. Attitude to language explains linguistic behavior in general, it's either positive behavior or negative behavior (Abdullah et al, 2012). Basically, both motivation and attitudes are intertwined with each other as per highlighted by Gardner's socio educational model of L2 acquisition noted that attitudes towards language learning situation support's the individual motivation to learn second language. He further clarified that, an excellent learner is unlikely to persist long enough to attain any useful language proficiency if there is no sufficient motivation instill within them. Whereas, regardless of learning aptitude, learning performance and achievements, if the learners are strongly motivated, he can simply acquire the L2 (Gardner, 1980).

A similar past study by Karahan (2007) on the relationship between the language attitudes towards the English language and its use in Turkey, had stated that the students had a mildly positive attitude in English language learning especially among the female students and they showed a higher rate compared to male students. Furthermore, a similar past study by Soleimani and Hanafi (2013) investigated on Iranian medical students' attitudes towards English language learning. The study focused on three aspects of attitude namely, emotional, cognitive and behavioral. The researchers had found that the Iranian medical students hold highly positive 
overall attitude regarding English language learning. In addition, Hargender Kaur (2014) examines a similar past research on to what extent the respondents use English at home and with their peers, to what extent are the respondents motivated to use and learn English and to what extent are the patterns of language use and attitudes related to their proficiency in English. It was highlighted that, the respondents generally had a positive attitude towards learning English and were motivated to learn it regardless of their family backgrounds and proficiency levels. A past research done by Ahmad, Abdullah and Ghani (2014) on their study about attitudes and motivation towards English language learning among Islamic studies students: exploring the teachers' view, they clarified that the Islamic studies students held negative perceptions toward English language and they claimed that the students are very weak in English language learning. Hence, it is of a great significance to explore the attitudes and motivation of Islamic studies students towards English language learning in UKM. This is due to the reasons that firstly, English have been learnt by the students since primary school up until tertiary education system for more than 10 years long. Secondly, Malaysia's government is very keen in improvising the quality and proficiency of Malaysian's English by implementing the CEFR framework. Thirdly, employers claimed that they prioritized fresh graduate who speaks proficient English to be offered a job, proved that the importance of English in tertiary education level in Malaysia. Lastly, Ahmad, Abdullah and Ghani (2014) regarding attitudes and motivation of Islamic studies students in English language learning held negative attitudes and lack of motivation in tandem of poor performance in English, suggested that future research should dig further into this matter as they clarified that there is relatively little research have been done on attitudes and motivation in English language learning among Islamic studies students. Therefore, the ambiguity of the previous research results suggests the need to delve further into the Attitudes and Motivations in English Language Learning among Islamic Studies Students in National University of Malaysia (UKM). This study will attempt to answer the following research questions: At the Faculty of Islamic Studies: 1. What is the students' attitude in English language learning? 2. What is the students' motivation level in English language learning?

\section{Literature Review}

\section{English in Malaysian Contexts}

For centuries, English has been known as Lingua Franca and according to Seidlhofer (2004), English as a Lingua Franca has been emphasized in the recent past for teaching and learning purposes. English language learning has becoming more significant when the government come out with concrete plans to ensure the continuity of the English language in terms of education and the nation's future development. As per claimed by Atef and Munir (2009); Hariati and Lee (2011); Mat and Yunus (2014), they clarified that the government plans regarding making Malaysia into an industrialized nation through vision 2020 and the setting up of multimedia super corridor (MSC) seems to influence the changes of the language policy in Malaysia education system as the awareness of the importance of English are growing. However, currently the government had proposed another policy called The Common European Framework of Reference or CEFR to enhance the English language learning in Malaysian education system. CEFR is now acknowledged internationally as the standard language proficiency framework and it has been introduced and applied by countries outside Europe such as Vietnam, Japan, and Indonesia and 
the framework was officially introduced to Malaysia in 2013. Thus, it shows how important the role of English language towards Malaysian education system that the government had been forced to take strong measurements in order to enhance the proficiency of English language learning among Malaysian.

Thus, the English language in Malaysian education system surely evolved positively in a way that, government is making a huge effort to ensure that English language learning in Malaysian education system is of the same level of proficiency level around the native country of English. With that efforts, people awareness on the importance of English in education and English for future career has becoming well accepted by majority of Malaysian including parents, students and teachers. There is no denial on the importance of English in Malaysian context, one of the obvious example is for the high scholars to further their study in degree, they need MUET certificate for them to be allowed study in local universities, and for them to further study oversea, they have to have IELTS or TOEFL certificates. Anyways, they need a certificate to confirm and validate their English proficiency level to be able to further their study in the respected fields. On the other hand, English in Malaysian context is not only focusing on education system alone, but also in seeking occupations. Additionally, as stated by Mirjana and Ana (2017)in them researches, the employers prioritized students' who are a good speaker of English as the most important criteria one's must possess in order for them to be offered a job. Despite whatever courses or programs the fresh graduates studied, when it comes to working world, employers are looking for someone who could speak fluent and good speaker of English. Thus, English in Malaysian context clearly shows that English plays a vital role in Malaysian education system also in working environment.

\section{Attitude}

In the preceding years, there's many past researchers who defined attitude differently. Baker (1992) defined attitudes as the determination and path of human behavior that is use to explain over a theoretical paradigm. Gardner (1980), defined the term attitude as an interpretation about the attitudes object based on theories. Additionally, Gardner (1980) elaborates on Likert's definition by defining attitudes as the individual fears, threats, and beliefs, institutions and feelings, preconceived notions, prejudice or bias, about any specified topic. The Longman Dictionary of Applied Linguistics and Language Teaching (2002) defined language attitudes as follows: "the attitudes which speakers of different languages or language varieties have towards each other's languages or to their own language. Expressions of positive or negative feelings towards a language may reflect impressions of linguistic difficulty or simplicity, ease or difficulty of learning, degree of importance, elegance, social status, etc. Attitudes toward a language may also show what people feel about the speakers of that language. Language attitudes may have an effect on second language or foreign language learning. The measurement of language attitudes provides information which is useful in language teaching and language learning." On the other hand, positive attitudes are believed to be able to bridge the gap between teacherlearner interaction in learning English as a second language (Mirjana and Ana, 2017).

There are relatively many past researches done on attitudes in English language learning. For instances, Karahan (2007) studied about the relationship between language attitudes towards the English language and its use in Turkey. The researcher used questionnaire to investigate 190 
eighth grade students of a private primary school in Adana, Turkey. Karahan (2007) presumed that the students have mildly positive attitudes toward English language learning. A past research done by Yang (2010) investigated on the attitudes of Chinese college students toward English, different varieties of English, and China English. The study has also investigated their attitudes toward the current English education policies and practices in China and their purposes for learning English. From the study, it has been proven that the Chinese college students have positive attitudes toward the English language and China English. It was also added that they are aware of different varieties of English and the majority of them consider nativization of English in China as a manifestation of Chinese culture. Interestingly, the author also clarified that the longer the students have studied English, the more likely they are to have positive attitudes toward English. The students' experience with native English-speaking teachers and their majors also explain their positive attitudes toward English (Yang, 2010).

Past research on English language majors in China showed that the learners are positive with English language learning and the learning of English is highly motivated in China (Liu, 2007; Liu and Zhao, 2011). A similar research on the non-English majoring students' attitudes towards learning cultural themes of different countries in an anonymous university in China was done by Liu and Laohawiriyanon (2013) highlighted that the students preferred to learn themes concerning their own culture compared to the thing of different countries. A study by Thao and Tham (2013) on the students' attitudes towards English language learning (ELL) and use of selfregulated learning (SRL) strategies at one college in Dak Lak, Vietnam stated in their findings that the number of years of learning English did not account for the participants' change of attitudes to English language learning. However, the authors further enlightened that the academic achievements and students' attitude in learning English are positively related to each other.

Abdulghani and Miao (2015) studied on the attitudes of local students towards the use of the English-Medium instruction in their programs in China. A semi-structured interviews with six graduate students majoring in different programs are conducted. From the interview, it was found that the participants hold very positive attitudes towards the use of the EMI strategy at their current programs. Therefore, the authors had recommended that the need for future research to study on the attitudes of local students and the factors behind their attitudes. A similar and yet recent study by Mirjana and Ana (2017) who examined about similarities and differences in attitudes and beliefs towards learning the German and the Italian language. The results stated that there was a slight difference between the learners of both German and Italian and the learners of German perceive the language as more difficult than Italian. Besides, it was noted by the authors that, the perception about the difficulty of the German language did not have an argumentative effect on the attitudes towards that language.

Moreover, future research suggested that researcher should emphasis more on the contextual factors such as individual, social and societal that affect targeted students' learning. These contextual factors can be considered from the perspectives of the language, the learner and the learning process (Karahan, 2007). Moreover, extensive needs analysis, multiple in depth interviews with students and teachers, document analysis of college English curricula and syllabus, and observation of English performance in actual working places in different contexts would be necessary (Yang and Yu, 2010). Abdulghani and Pei Miao (2015) recommended that the need for future research to study the attitudes of local students and the factors behind their 
Vol. 10, No. 2, 2021, E-ISSN: $2226-6348$ @ 2021 HRMARS

attitudes. Hence, there is relatively many research on the students' attitude in English language learning among the non-English majoring students however, there is very few research done on attitudes and motivation in English among the Islamic studies students.

\section{Motivation}

Motivation according to Gardner (1985), is defined as the composing of aimed progress, invested effort and positive attitude that is desired to be achieved. However, Gardner (2006) claimed that motivation is very hard to define because motivation is simply a wonder with many features. Brown (2000) highlighted that motivation is simply an anticipation of reward. He further defined the term motivation as the degree of effort they exert in respect to their choices they make as to what aim they will approach or avoid. According to Dehbozorgi (2012), emotional variables like attitudes, motivation and anxiety are considered important in the process of language learning as it is equally significant as aptitude, intelligence, age, and personality (Abdul Aziz, 2007). Abdul Aziz (2007) highlighted that learner's attitude towards language learning is regarded as one of the key factors that motivate the learners to learn a language and this statement are agreed by Mirjana and Ana (2017) who noted that motivation result from attitudes. Therefore, both motivation and attitudes are now proven that these two are closely related to each other.

There are relatively many past researches done on motivation and attitude in English language learning as to compare to find a research solely on motivation which is hard because both motivation and attitude are interrelated. Previous research done by Arifin (2014), explored about Petroleum Engineering students' motivation and attitudes towards learning the English language. For the students' motivation, the findings showed the subjects' greater support of instrumental reasons for learning the English language including utilitarian and academic reasons. However, regarding the integrative reasons, the results provided evidence that learning English as a part of the culture of its people had the least impact in students' English language motivation. In addition, students' attitudes revealed that most of students had positive attitudes towards the social value and educational status of English. Past research by Abdullah et al (2012) who studied about attitude of the undergraduate students of Life Science School of Khulna University towards English language. The researchers use the Behaviorist view \& Mentalist view (Fasold, 1984) to govern the framework of the study. From the findings, it was proven that the respondents were found to be positive towards English language and this could be attributed to the fact that respondents were instrumentally motivated towards English.

Previous study by Thao and Tham (2013) investigated the students' attitudes towards English language learning (ELL) and use of self-regulated learning (SRL) strategies at one college in Dak Lak, Vietnam. This study involved 241 non-English majors taking part in answering a questionnaire. The authors had stated in their findings that the number of years of learning English did not account for the participants' change of attitudes to English language learning. However, the authors further enlightened that the academic achievements and students' attitude in learning English are positively related to each other (Thao and Tham, 2013). Although this research study on only the attitude of the students, the researcher had suggested that for future research to examine on both attitude and motivation of the students in regard of the English language learning and to promote the importance of self-regulated learning (SRL) strategies in language instruction. 
A research by Kaur (2014) examined to what extent the respondents use English at home and with their peers, to what extent are the respondents motivated to use and learn English and to what extent are the patterns of language use and attitudes related to their proficiency in English. The study comprised a questionnaire distributed to 30, 14 years old respondents from different ethnic groups and different background from a semi-urban secondary school in Malaysia. The questionnaire was designed to obtain information about the respondents' use of English, their attitudes towards English and their motivation for learning English. Kaur (2014) indicated that the respondents as a whole hold a positive attitude towards learning English and were motivated to learn it regardless of their family backgrounds and proficiency levels. Kaur (2014) also notified that the respondents whose parents held professional jobs tended to be more proficient than those whose parents did not. Furthermore, a research by Liu and Zhang (2013) who investigated on the attitudes and motivation in English language learning among the Chinese students. The researchers used a large number of subjects who participated from several universities in China had found that the subjects who demonstrated a low level of integrative motivation spent less time learning, and adopted the target language less slow with respect to the subjects who had a substantially high level of integrative motivation.

\section{Attitude and Motivation towards English in Malaysian Contexts}

English is a language spoken and written by billions of people across the globe. One's to be able to be proficient in English is undeniably important, especially in Malaysia's context where the language has been appointed as a second language status (Gill, 2002). In Malaysia's context, most of Malaysians spend up to eleven years of education in primary school and secondary school (The Malaysia Government Official Portal, 2012) with English as one of the compulsory subjects taught in schools. Even now, English is a subject where students can't fail for them to be able to get an offer from Universities and to further their studies in tertiary level education. The awareness on how important English language in Malaysia is evident in the tertiary education and job entry requirements (Nich, 2005; Shanta, 2000; Ball and Chick, 2001).

Consider the importance of English language nowadays in Malaysia context, the attitudes and motivations toward English among the Malaysian should be positive, however there is a quiet number of people that is still regarded English as the colonial language though English has been regarded as our second language. Thus, this perception will lead to negative attitudes and eventually demotivated the Malaysian students to learn English language. Some of Malaysian might feel uncomfortable when they hear other Malaysian speaking in English while walking down the street. A few of the typical Malaysian will say that those who speak English is trying to show off by using English instead of Bahasa Malaysia or Mandarin or Tamil.

A past research done on the attitudes and motivations of the secondary school students in learning English and it was highlighted that the students have positive attitudes towards English and the learning of the language (Melor and Rashidah, 2011; Noraini and Noorizah, 1999, Adnan, 1985; Azmi, 1995). The findings also yield similar results of other researchers, which even though students were highly motivated to learn English, but they tend to labor minimal efforts in their learning process (Melor and Rashidah, 2011). Malaysian students are more extrinsically motivated than intrinsically motivated (Madziah and Isarji, 2009; Samsiah et al., 2009; Liu, 2007; Thang et al., 2004). As agreed by several researchers (Ainol Madziah and Isarji, 2009; Samsiah et 
al., 2009; Thang, 2004), this phenomenon is a common practice among Malaysian students and the issue should be immediately addressed so as to encourage students to take greater responsibility for their own learning and not taking learning process for granted. Therefore, as mentioned by past researchers, Malaysian students portrays positive attitudes and motivation when it comes to learn English. It can be presumed that Malaysian's students are well aware of the importance of English, besides learning it as a compulsory subject in school, having the right attitude towards English will eventually motivate students to learn the English language as a second language.

\section{Research Method \\ Participants}

The target participants for this study is from students from faculty of Islamic studies in National University of Malaysia (UKM). The number of target participants is one hundred samples and according to Conroy (2012) in his book namely Sample Size: A rough Guide, he suggested that a good maximum sample size is usually $10 \%$ as long as it does not exceed 1000 . Therefore, in this study, the total population of Islamic studies students are around 1000 people and $10 \%$ from the population is 100 . The total number of participants is 100 and all of them are Malays, Malay language is their mother tongue, Arabic is their second language and English is regarded as their foreign language. Majority of the participants age between 21 to 23 years old and they are among the third year students. In terms of MUET result, the average of the Islamic studies students obtained band 3 .

\section{Instrument}

A set of questionnaire are adapted from Abdullah et al (2012) that investigated on the attitude of the undergraduate students of Life Science School of Khulna University towards English language and Thang, Ting, and Nurjannah (2011) investigated on the attitudes and Motivation of Malaysian Secondary Students towards learning English as a Second Language. A quantitative method design with the used of close ended questions and the used of Likert scale from strongly agree (4), agree (3), disagree (2), to strongly disagree (1) are applied in the questionnaire. The questionnaire is consisted of three parts; Part A consisted of demography characteristics of the respondents which included gender, race, MUET result and the first and second language of the participants. Part B consisted of questions about the students' attitudes in English language learning while Part $C$ consisted of questions about the students' motivation level in English language learning. Part B answered the first research question on 'What is the attitudes in English language learning among the Islamic studies students in UKM?' As well, Part C answered the second research question on 'What is the motivation level in English language learning among the Islamic studies students in UKM?'

\section{Findings}

\section{Demographic Information}

From the total of $100 \%$ respondents, the findings show that a total of $26 \%$ are made up from male respondents, while the other total of $74 \%$ are made up from the female respondents. Thus, the majority of the respondents are from female respondents on the other hand, male 
respondents are considered the minority in which female respondents in this research obviously outweighed the number of male respondents, making it inequivalent. From the table 4.1 .1 shows that majority of the respondents are age between 21 to 23 years old and they are mainly from the third year students. These Islamic studies students differs in age because some of them are from diploma holder, Sijil Pelajaran Malaysia (SPM) holder, Sijil Tinggi Pelajaran Malaysia (STPM) holder, Sijil Tinggi Agama Menengah (STAM) holder, and matriculation holder and that is why their age varies differently although they may be in the same year.

Table 4.1.1 shows the demographics characteristics of the Islamic studies students.

\begin{tabular}{|l|l|l|l|}
\hline Demographics Characteristics & Mode & Mean & S.D \\
\hline Age & 21-23 years old & 2.22 & 1.29162 \\
\hline Years of Studies & Third year & 2.35 & 1.01876 \\
\hline First Language (L1) & Malay & 1.00 & 0.00000 \\
\hline Second Language (L2) & Arabic & 3.67 & 1.51127 \\
\hline
\end{tabular}

From the findings shown in table 4.1 .1 above, it can be noted that the total number of $100 \%$ of the respondents are among Malays. Therefore, it is justified that the respondents' mother tongue is Malay language. However, for the respondents second language, with a total number of $56 \%$ of the respondents claimed they speak Arabic and shortly followed with $44 \%$ of the respondents highlighted that they speak English as their second language. Therefore, it can be presumed here that the respondents among the Islamic studies students speak their mother tongue language which is Malay language, they also speak Arabic as their second language and they speak English as their foreign language. The band in the MUET results varies in terms of aggregate score and the proficiency level. For band 1, the aggregate score is below 100 and in terms of proficiency level, they are very limited user of English. Next, for band 2, they usually score around 100 to 139 and that make them a limited user of English. After that, for band 3, they sore 140 to 179 and they are considered as the moderate user of English. Moving on to band 4, they are regarded as the satisfactory user of English and they usually score between 180 to 219 . The proficient user of English is among the band 5 students in which, they scored between 220 to 259. Lastly, for those who got band 6, they are one of the highly proficient user of English where their score is between 260 and 300. 
INTERNATIONAL JOURNAL OF ACADEMIC RESEARCH IN PROGRESSIVE EDUCATION AND DEVELOPMENT

Vol. 10, No. 2, 2021, E-ISSN: 2226-6348 @ 2021 HRMARS

Table 4.1.2 shows the MUET results according to the gender of the Islamic studies students.

\begin{tabular}{|c|l|l|l|l|}
\hline \multirow{2}{*}{ MUET } & \multicolumn{2}{|c|}{ Gender } & \multirow{2}{*}{ Mean } & S.D \\
\cline { 2 - 3 } & Female & & & \\
\hline Band 1 & $14 \%$ & $9 \%$ & 1.65 & \\
\hline Band 2 & $13 \%$ & $13 \%$ & 1.65 & 0.48698 \\
\hline Band 3 & $18 \%$ & $14 \%$ & 1.81 & 0.48516 \\
\hline Band 4 & $10 \%$ & $3 \%$ & 1.91 & 0.39656 \\
\hline Band 5 & $3 \%$ & $3 \%$ & 1.67 & 0.28868 \\
\hline Band 6 & $0 \%$ & $0 \%$ & 0.00 & 0.51640 \\
\hline
\end{tabular}

By referring from the table 4.1.2 above, it was clearly stated that majority of the respondents got band 3 in their MUET examination, followed by band 2, band 1, band 4, band 5 and none of the respondents got band 6 . Hence, basically with a total of $32 \%$, average of the Islamic studies students got band 3 in their MUET examination and minority of them barely got band 5 with only $6 \%$. Thus, it can be said that the Islamic studies students majorly are the moderate user of English language and none of them actually got band 6 and that generally clarified that none of the Islamic studies students are the highly proficient user of English.

\section{Research Questions 1: What is their attitudes towards English?}

As can be seen in table 4.2 above, from the findings, majority of the respondents stated that they like to speak English with a total score of $(x=2.80)$ which shows that they are actually projecting a positive attitude toward English plus, this can be related with the statement "When someone speaks English it creates a good impression of him or her". This statement accumulated a total score of $(x=2.75)$ which indicates that majority of the respondents are actually did partaking positive attitudes in English language learning. According to table 4.2 above, it can be seen that, the highest mean is $(x=2.91)$ and this is when the respondents were asked about whether they prefer English through informal learning rather than formal learning and majority of the respondents preferred to learn English through informal learning with a total percentage of $72 \%$. Furthermore, a total of $73 \%$ of the respondents are both agreed and strongly agreed that knowledge of English offers advantages in seeking good job with a total mean score of $(x=2.90)$ which place as the second highest mean among others. When the respondents were asked about if they want to study more English and whether English should be the medium of instruction in tertiary education, a big sum of $67 \%$ respondents agreed and strongly agreed with a mean score 
Vol. 10, No. 2, 2021, E-ISSN: 2226-6348 @ 2021 HRMARS

of $(x=2.80)$. Besides, with a total mean score of $(x=2.63)$, popular opinions from the respondents agreed and strongly agreed that they will choose to read academic texts in English if they were given a choice to choose to read either in English or in Bahasa Malaysia. Similarly, when asked about if they prefer to read newspapers and magazines in English, majority of them showed positive attitudes with a total score of $(x=2.63)$.

Table 4.2 shows the attitudes of Islamic studies students toward English

\begin{tabular}{|c|c|c|c|c|c|c|}
\hline Questions & SD & D & A & SA & Mean & S.D \\
\hline $\begin{array}{l}\text { When someone speaks English it } \\
\text { creates a good impression of him or } \\
\text { her. }\end{array}$ & $8 \%$ & $30 \%$ & $41 \%$ & $21 \%$ & 2.75 & 0.88048 \\
\hline $\begin{array}{l}\text { Knowledge of English offers } \\
\text { advantages in seeking good jobs. }\end{array}$ & $7 \%$ & $20 \%$ & $49 \%$ & $24 \%$ & 2.90 & 0.84686 \\
\hline $\begin{array}{l}\text { I would like to study more English } \\
\text { and English should be the medium } \\
\text { of instruction in tertiary studies. }\end{array}$ & $10 \%$ & $23 \%$ & $44 \%$ & $23 \%$ & 2.80 & 0.91010 \\
\hline $\begin{array}{l}\text { If an academic text is available in } \\
\text { English and in Bahasa Malaysia, I } \\
\text { will read the text in English. }\end{array}$ & $9 \%$ & $33 \%$ & $44 \%$ & $14 \%$ & 2.63 & 0.83672 \\
\hline $\begin{array}{l}\text { I prefer my peers could speak to me } \\
\text { in English. }\end{array}$ & $11 \%$ & $33 \%$ & $40 \%$ & $16 \%$ & 2.61 & 0.88643 \\
\hline $\begin{array}{l}\text { I prefer the lecturer to speak full } \\
\text { English during the English subject } \\
\text { class. }\end{array}$ & $13 \%$ & $34 \%$ & $37 \%$ & $16 \%$ & 2.56 & 0.91365 \\
\hline $\begin{array}{l}\text { I would like to read more } \\
\text { newspapers and magazines in } \\
\text { English. }\end{array}$ & $11 \%$ & $32 \%$ & $40 \%$ & $17 \%$ & 2.63 & 0.89505 \\
\hline $\begin{array}{l}\text { Whenlhaveproblemin } \\
\text { understanding some of the English }\end{array}$ & $12 \%$ & $25 \%$ & $40 \%$ & $23 \%$ & 2.74 & 0.94943 \\
\hline
\end{tabular}




\section{DEVELOPMENT}

Vol. 10, No. 2, 2021, E-ISSN: 2226-6348 @ 2021 HRMARS

\begin{tabular}{|l|l|l|l|l|l|l|}
$\begin{array}{l}\text { words, I would immediately find the } \\
\text { meaning of the words. }\end{array}$ & & & & & & \\
\hline $\begin{array}{l}\text { I prefer learning English through } \\
\text { informal learning i.e. listen to } \\
\text { music, and watching movies instead } \\
\text { of formal learning i.e. in the } \\
\text { classroom. }\end{array}$ & $6 \%$ & $22 \%$ & $47 \%$ & $25 \%$ & 2.91 & 0.84202 \\
\end{tabular}

Additionally, it was visibly noticeable that the respondents are projecting positive attitudes because they majorly agreed and strongly agreed as they preferred their peers to speak English to them and they also preferred the lecturer to speak full English during English subject class with a respective total score of $(x=2.61)$ and $(x=2.56)$. The respondents also showed tremendous positive attitudes when asked about if they encounter problem in understanding some of the English words, and if they would immediately find the meaning of the words. For that, with a total score of $(x=2.74)$, average number of the respondents are immensely prominent in learning English by possessing their positive attitudes toward English.

\section{Research Question 2: What is the motivation level in English Language Learning among students?}

As per showed in the table 4.3 above, it can be presumed that the highest total score of mean accumulated is $(x=2.97)$ which explains the popular opinions that drive the students to learn English is due to the reason that the Islamic studies students do acknowledged that English is important for their future career and this is the major motivation that appeal to the respondents. Moreover, the respondents also agreed and strongly agreed that another major motivation for them to learn English is to improve their English skill which made up a total score of $(x=2.87)$ which placed second of all. The third motivation that drives the respondents are when they actually feel confident when speaking English and this statement accumulated a total score of $(x=2.86)$ that placed third among others.

Outstandingly, one of the popular opinions of the respondents with a total $74 \%$ agreed and strongly agreed that, they learn English because our religion urges us to learn the other languages that made up a total score of $(x=2.83)$ which placed fourth. Plus, interestingly, the respondents have high motivation when it comes to lean English as they positively agreed and strongly agreed that they learn English because they want to be more at ease with English speakers $(x=2.81)$, they enjoy learning English ( $x=2.77)$, they study English because it is something they always wanted to do $(x=2.68)$ and English helps them to play games better $(x=2.58)$.

However, as can be seen form the table 4.3 above, the lowest total score of mean is $(x=2.27)$ refer to the statement "I feel that no one is really educated unless he is fluent in English language". A total of $54 \%$ disagreed and strongly disagreed to this statement while $46 \%$ of the 
respondents appears to agree and strongly agree with this statement. With only a slight difference in number of respondents, this statement seems a bit ambiguous and underrated for some people. Besides, when asked about "I study English in order to please my family" surprisingly collects vague response as in $50 \%$ of the respondents agreed and strongly agreed to it, another $50 \%$ are disagreed and strongly disagreed by the respondents with a total score of mean $(x=2.37)$, which placed the second lowest of all.

Table 4.3 shows the motivation of Islamic studies students toward English

\begin{tabular}{|l|l|l|l|l|l|l|}
\hline \multicolumn{1}{|c|}{ Questions } & SD & D & A & SA & Mean & S.D \\
\hline $\begin{array}{l}\text { Learning English is important for } \\
\text { my future career. }\end{array}$ & $4 \%$ & $21 \%$ & $49 \%$ & $26 \%$ & 2.97 & 0.79715 \\
\hline $\begin{array}{l}\text { I learn English to be more at ease } \\
\text { I learn English because our religion } \\
\text { urges us to learn other languages. }\end{array}$ & $10 \%$ & $20 \%$ & $49 \%$ & $21 \%$ & 2.81 & 0.88415 \\
\hline & & & $56 \%$ & $18 \%$ & 2.83 & 0.82945 \\
\hline I study English in order to please my & $23 \%$ & $27 \%$ & $40 \%$ & $10 \%$ & 2.37 & 0.94980 \\
\hline family & & & & & & \\
\hline & & & & & & \\
\hline Ilearn English to help me to play & $15 \%$ & $26 \%$ & $45 \%$ & $14 \%$ & 2.58 & 0.91210 \\
\hline game better. & & & & & & \\
\hline & & & & & & \\
\hline I feel that no one is really educated & $28 \%$ & $26 \%$ & $37 \%$ & $9 \%$ & 2.27 & 0.97292 \\
\hline unless he is fluent in English & & & & & & \\
\hline language. & & & & & & \\
\hline & & & & & & \\
\hline I learn English in order to improve & $9 \%$ & $18 \%$ & $50 \%$ & $23 \%$ & 2.87 & 0.87219 \\
\hline my English language skills. & & & & & & \\
\hline & & & & & & \\
\hline I learn English because it is & $14 \%$ & $21 \%$ & $48 \%$ & $17 \%$ & 2.68 & 0.91982 \\
\hline something that I always want to do. & & & & & & \\
\hline & & & & & & \\
\hline I study English because I enjoy & $12 \%$ & $21 \%$ & $45 \%$ & $22 \%$ & 2.77 & 0.93046 \\
\hline learning it. & & & & & & \\
\hline & & & & & & \\
\hline I feel more confident when learning & $7 \%$ & $23 \%$ & $47 \%$ & $23 \%$ & 2.86 & 0.85304 \\
\hline English. & & & & & & \\
\hline & & & & & & \\
\hline
\end{tabular}




\section{Discussions}

\section{The attitude in English Language Learning (Research Question 1)}

This part will discuss about the attitudes in English language learning among Islamic studies students. According to the findings, it was informed that the entire respondents of Islamic studies students are from Malays' race. Plus, it was noted the Islamic studies students use their mother tongue language which is Malay language as their first language. In the meantime, for their second language, majority of the Islamic studies students literally speak Arabic compared to English. Therefore, English is considered as the foreign language among the Islamic studies students as they speak Arabic for their second language. This is parallel to previous research done by Ahmad, Abdullah, and Ghani, (2014) that examined on the Attitudes and Motivation Toward Learning the English Language among students from Islamic Education System Background: Exploring the Views of Teachers and what they have found is that, the students prefer to use Arabic language as the medium to communicate between themselves and between them and the teachers. In contrast with past research from Gill (2002), from his findings, he confirmed that English is placed as the second language in Malaysia and in line with the education policy; English is taught as a second language. On that note, it was assumed that generally, English have been using as second language among Malaysian but it does not apply to the Islamic studies students in UKM because they stated that they speak Arabic for their second language, and officially English is the foreign language to them.

The fact that English is viewed as the foreign language among the Islamic studies students and this consequently proved that they are not familiar with English because English is literally foreign to them. UKM itself does not urge their students to speak in English, because UKM stand's is always toward promoting and utilizing Malay language rather than English language. Apart from program such as English Language Studies (ELS), English as a Second Language (TESL), and Medic programs, all of the other programs in UKM need and compulsory to do their thesis in Malay language including programs within the faculty of Islamic studies, law program, engineering program and psychology program. Ahmad, Abdullah, and Ghani, (2014) detailed that the Islamic studies students hardly speak the English language and this may be due to the lack of confident of the respondents to actually utilize and speak English. Plus, they further notified that, from the findings, the teachers claimed the students seldom to use English to interact in the class. Thus, in relation with this research, this could actually contribute to the attitude of the Islamic studies students because they have little exposure to English in their tertiary education level here in UKM.

From the findings, it was proven that the respondents were found to be projecting positives behavior and attitudes toward English language despite English is viewed as a foreign language among the Islamic studies students. However, the Islamic studies students past experiences during primary and secondary schools in English language learning should not be neglected as per said by Kaur (2014), Malaysian students have been exposed to English subject for more than ten years. Even though they are exposed to English for merely ten years, the Islamic studies students still viewed English as a foreign language. This is entailed with past research by Thao and Tham (2013) stated in their studies that, durations of learning English doesn't influence one's attitudes. Therefore, it is clear enough why more than ten years of learning English through primary school and secondary school up until tertiary education doesn't change the students' 
attitudes, and what can change them is their self-attitude. Therefore, from the findings, the Islamic studies students are projecting positive attitudes when it comes to learn English despite their lack of exposure in English.

Additionally, based on the findings, the Islamic studies students claimed that, they would like to study more English and English should be the medium of instruction in tertiary education level. Through this clarification, it is assumed that the Behaviorist view by Skinner (1990) proved that the Islamic studies students' projected positive reinforcements by showing positive attitudes when it comes to learning English. Furthermore, as per highlighted by Alptekin (2002), English language is an important medium of interaction when it comes to academic as English have been used among various people across the world. The Islamic studies students are not compulsory to learn English as much as they have to learn Arabic considered that Arabic is their second language. This is one of the reasons why, the less activities of using English language have caused the Islamic studies students to be less proficient in English language learning. However, it's good to know that, they possess positive attitudes in English language learning, although they didn't get to study and employ English in their daily basis. Constituent with the findings, a similar past research done by Karahan (2007) studied about the relationship between language attitudes toward the English language and its use in Turkey. Karahan (2007) concluded that the students have a mildly positive attitudes toward English language learning. This mildly positive attitudes are due to the fewer exposure of English language towards the students. Similarly, in this research, from the findings, the Islamic studies students projecting positive attitudes when it comes to English as they claimed that they would like to study more English and English should be the medium of instruction in tertiary education level despite the little exposure of English towards them and Skinner (1990) view on Behaviorist is proven.

Ironically, even though the Islamic studies students love to speak in English, they didn't get to speak in English as much as they want. This is due to the reason that the Islamic studies students didn't have the opportunity to learn and utilize English in the classroom and outside of the classroom (Ahmad, Abdullah, and Ghani, 2014). On that note, form the findings, it was noted that the Islamic studies preferred to learn English through informal learning rather than formal learning. The reason behind their choices to learn English through informal learning is because they didn't get exposed to English in the class anyway, therefore, they might as well learn English through self-regulated learning where they can do the learning on their terms while having fun. Past studies by Thao and Tham (2013), who studies about the attitudes toward English language learning and the use of self-regulated learning strategies defined self-regulated learning as a learning that actively employ a variety of learning behaviors or strategies to achieve self-set goals. Zimmerman (2008), explained that the self-regulated learning also relies on motivational, and behavior feedback to modify or adjust their behaviors and strategies when initially unable to attain their goals. Thus, self-regulated learning is assumed to be able to help the Islamic studies students to learn English. Behaviorist view was first proposed by Skinner (1990), according to him, language learning is a process known as operant conditioning. Conditioned behavior is the result of repeated training, while operant behavior is the result of learner's own free will and it is not forced. Thus, Skinner's operant behavior is constituent with this research which promotes the process of learning should be based on the learner's free will and should not be forced. Consequently, from the findings, it can be presumed that the Islamic studies students are highly 
positive in regard to their attitudes in English language learning, in contrast with previous research done by Ahmad, Abdullah, and Ghani, (2014) that examined on the Attitudes and Motivation Toward Learning the English Language among Students from Islamic Education System Background in which they clarified that the Islamic studies students possess mildly negative attitudes in learning English and furthermore, they students are proven to have lack of motivation when it comes to learn English. Additionally, it is also proven that the Behaviorist view proposed by Skinner (1990) is evident in this research in which the Islamic studies students do incorporated the operant behavior in their learning and they also project positive reinforcement in another words, the Islamic studies students possess positive attitudes toward English language learning.

\section{Motivation among Islamic Study Students (Research Question 2)}

This part will discuss about the motivation in English language learning among Islamic studies students. When it comes to motivation, Skinner (1990) explained in his Behaviorist view that motivation is an operant behavior and that is divided into two kinds of reinforcements which are positive reinforcement and negative reinforcement. Positive reinforcement are praises and rewards whereas negative reinforcement are punishments and rebuke (Skinner, 1990). The concept of reinforcements is constituent with Deci and Ryan (1985) theory on extrinsic and intrinsic motivation where they explained that the students learn for the sake of rewards and punishments. Skinner (1990) stated that motivation and attitudes are closely related. Since the attitudes of the Islamic studies students are believed to be positives, the motivation of the Islamic studies students are yet to be determined whether it is intrinsic or extrinsic motivation. From the findings, it can be seen that majority of the Islamic studies students got band 3 in their MUET examination and none of the Islamic studies students actually got band 6. For those Islamic studies students who got band 3, they are considered as the modest user which also indicated that the respondents are fairly fluent, fairly appropriate user of the language and also many grammatical errors and since none of them got band 6, it can be assumed that none of the Islamic studies students are highly proficient user of English language.

Since the Islamic studies students are modest user of English, they are expected to have negative attitudes and low motivation in learning English. A past research by Thang, Ting, and Nurjanah (2011) stated that, the proficiency level of the learners, influences the attitudes and the motivation level of the learners. Nevertheless, the Islamic studies students in UKM seems to be in contrary with the past research done because they possess positive attitudes and high motivation level in English language learning. According to the findings, it was presumed that, the biggest motivation that drive the Islamic studies students to learn English is due to the importance of English for their future career. The students are very much aware and acknowledged the important of English language for them to be guaranteed a job in the near future. According to Kaur (2014), she claimed that employers are looking for graduates that have competent command of English, and therefore, English language is very crucial and vital in order to ensure that the Islamic studies students are capable of securing a job once they graduated.

The Islamic studies students realized the fact that they not need only to be good at Arabic in which they considered to be their second language, but they have to be good at English too because English hold the key to better opportunity in their career. The awareness on how 
important English language in Malaysia is evident in the tertiary education and job entry requirements (Kaur, 2012). Consequently, past research by Thang, Thing and Nurjanah (2011) in their research about attitudes and motivation of Malaysian secondary school students in regard to English language learning clarified that Malaysian students are mostly responsive of the importance of English for their future career and the students are intrinsically motivated by factors such as desire to be excellent in academic performances and career advancement to improve English. Therefore, the Islamic studies students are seen to be intrinsically motivated in learning English with a goal to get a decent job once they graduated. This is parallel with Skinner (1990) in his behaviorist view that explained why Islamic studies students possess positive attitudes that is because they have positive reinforcements in which they learn English for the sake of doing what they want to do and they have purpose and that purpose is to seek for a job. Moreover, based on the findings, it can be acknowledged that the Islamic studies students are intrinsically motivated to learn English because they want to be more at ease with the English speaker. Meaning here, the students want to be able to fully understand when they are having a conversation with English speaker. The Islamic studies students apparently want to be understood when they conversing and they want to be able to engage in a meaningful conversation. As per said by Thang, Thing and Nurjanah (2011), extrinsic motivation does not always produce for a better performance. However, a few number of students are partaking intrinsic motivation because they are motivated to learn English for their own sake and personal rewards (Thang, Thing and Nurjanah, 2011). This also constituent with Skinner (1990) Behaviorist view regarding the positive reinforcements of the learners as the result of the operant behavior. Therefore, it can be said that the Islamic studies students are motivated to learn English to improve their English skills in a way to be the better version of themselves and it is for their personal achievements.

Previous research done by Atif and Munir (2009), explored about Petroleum Engineering students' motivation and attitudes toward learning the English language in Yamani context, the researches stated that academic reasons is one of the greatest reasons that drive the students' motivation in learning English. The petroleum students are compulsory to learn English and they are very much exposed to English language learning compared to Islamic studies students in UKM. Despite the great exposure to English and English is the medium of interaction, the Petroleum Engineering students nonetheless appear to have low proficiency level in English. Noted by Atif and Munir (2009), as a result of the petroleum engineering students' poor performance in English, most of the petroleum graduates have been rejected when applying to work at the oil companies. Hence forth, these students' biggest motivation to learn English is to get good marks for their academic requirements consequently they are hoping it will increase the opportunities in getting a job.

Additionally, another underrated motivation that the Islamic studies students disagree with is they did not view an individual who is not an English speaker as uneducated. They love to speak in English but they did not stereotype people who did not speak English as lacking. This is also considered as positive attitudes but toward the non-speaker of English. This attitude is much needed in the society nowadays because language is culture, and mutual respect towards one's culture is very important to ensure that we are projecting our own culture to them by respecting them the non-speaker of English. This is because, at first English was introduced in Malaysia 
during the colonial days, Malays claimed that English is a colonial language and they are rejecting English back then. However, through time and efforts done by government to change the colonial mindset of Malays people it has made possible through culture. For example, government open the opportunity for students to be an exchanged student to overseas and they went there to study, came back to work in Malaysia, and that's how English is spread across the country because people are convinced that English is vital in this era of globalization.

Lastly, the Islamic studies students claimed that they feel more confident when they learn English. Confidence can be very crucial for some people as some people have no problem speaking English in front of the public eyes however, few people will get panic attack or even anxiety when speaking in public. According to Lucas (2011), fear of speaking English in front of public and lack of confident are the major reasons why people develop second language anxiety. Lindy (2006) added that, second language anxiety are the results when interacting with native speakers of English. Lack of confident, and skills deficit indicate the most frequent source of anxiety. She further noted that speakers from China, Korea and Japan were amongst the most anxious language learners than other ethnic groups when it comes to second language anxiety. Therefore, confident level plays a very significant role when speaking or learning English, that is because, there is no right or wrong in learning process, motivation is what keeps us going.

\section{Conclusion}

The aim of this study is to shed lights on The Attitudes and Motivation in English Language Learning among the Islamic studies students in National University of Malaysia (UKM). Majority of the Malaysian students still have low proficiency level in English language consider that English language has been applied for more than ten years long in Malaysia education system. From the findings, it is presumed that generally the Islamic studies students possess positive attitudes in English language learning in a way that they love to speak English and they put a lot of effort in learning English such as, they will immediately search for the meaning of the words if they don't understand certain words they come across, they also prefer to read academic text, magazines and newspapers in English language rather than Malay language.

The Islamic studies students also enjoy to learn English through informal learning and they incorporated the self-regulated learning when it comes to English language learning. In terms of motivation level, the Islamic studies students elicit higher level of intrinsic motivation as they clarified that their biggest motivation when it comes to learn English is that they are well aware of the important of English for their future career. Additionally, the Islamic studies students are motivated to learn English because they want to polish their English skills so that they could speak with speaker of English easily. The Islamic studies students also notified that they feel extremely confident after they learn English. Therefore, the Islamic studies students have positive attitudes in English language learning, and they also intrinsically motivated towards English language learning.

\section{Acknowledgements}

This research was supported by the research grant FRGS/1/2016/SS09/UKM/02/3. 
INTERNATIONAL JOURNAL OF ACADEMIC RESEARCH IN PROGRESSIVE EDUCATION AND

DEVELOPMENT

Vol. 10, No. 2, 2021, E-ISSN: 2226-6348 @ 2021 HRMARS

\section{References}

Abdulghani, M., \& Pei, M. (2015). Chinese Students' Attitudes towards the Use of Englishmedium Instruction into the Curriculum Courses: A Case Study of a National Key University in Beijing. Journal of Education and Training Studies. Retrieved from http://jets.redfame.com

Abdullah, L. (2012). Students' Attitudes towards English: The Case of Life Science School of Khulna University. International Review of Social Sciences and Humanities, 3(1), 200-209. Retrieved from www.irssh.com

Ahmad, S., Abdullah, H., Ghani, A. (2014). Attitudes and Motivation toward Learning. The English Language among Students from Islamic Education System Background: Exploring The Views of Teachers. Journal of Education and Learning. Vol.8 (3) pp. 195-208.

Altbach, P. G., \& Knight, J. (2007). The internalization of higher education: Motivations and realities. Journal of Studies in International Education, 11, 290-305. http://dx.doi.org/10.1177/1028315307303542

Azizan, Hariati, H., \& Lee, Y., M. (2011). Top jobs only for those who know the language well. The Star Online. Retrieved 12 November 2012 from http://www.thestar.com.my

Adnan, Kamis. (1985). Pertalian antara sikap pelajar terhadap mata pelajaran dan kaitannya dengan pencapaian akademik. Jurnal Pendidikan, 10: 17-30.

Ainol, Madziah, Isarji, \& Sarudin. (2009). Motivation to Learn a Foreign Language in Malaysia. GEMA Online Journal of Language Studies, 9: 73-87.

Ahmad, S., Abdullah, H., Ghani, A. (2014). Attitudes and Motivation toward Learning: The English Language among Students from Islamic Education System Background: Exploring The Views of Teachers. Journal of Education and Learning. Vol.8 (3) pp. 195-208.

Arifin. (2014). The Attitudes of Distance Learning Students at the UKM's Faculty of Islamic Studies Towards Learning Arabic Language Skill Courses. Turkish Online Journal of Distance Education-TOJDE 15(1), 1302-6488.

Atef, T., \& Munir, S. (2009). Motivation and Attitudes Towards Learning English: A Study of Petroleum Engineering Undergraduates at Hadhramout University of Sciences and Technology. GEMA Online Journal of Language Studies. 9(2), 29-55.

Ball, R., \& Chik, R. (2001). Early Employment Outcomes of Foreign and Educated Graduates the Malaysian Experience. Springer Netherlands, 42: 171-189.

Baker, C. (1992). Attitudes and Language. Clevedon: Multilingual Matters Ltd.

Brown, H. (2000). Principles of language learning and teaching. New Jersey: Prentice Hall.

Crossey, M. (2008). English for global peacekeeping. Current Issues for Language Planning, 9(2), 207-218. http://dx.doi.org/10.1080/14664200802139448

Chalak, A., \& Kassaian, Z. (2010). Motivation and Attitudes of Iranian Undergraduate EFL Students towards Learning English. GEMA Online Journal of Language Studies 37, Volume 10(2)2010, pp. 37-56. Available online: http://ejournals.ukm.my/gema/article/view/108/99

Evan, S. (1999). The medium of instruction in the engineering steam at tertiary level in Hong Kong. Educational Journal, 27(2), 12-41.

Elsadig, H. (2017). Students' attitudes and motivation toward English language - Dongola University. International Journal of English and Literature (IJEL). 7(2), 55- 64 
INTERNATIONAL JOURNAL OF ACADEMIC RESEARCH IN PROGRESSIVE EDUCATION AND

DEVELOPMENT

Vol. 10, No. 2, 2021, E-ISSN: 2226-6348 @ 2021 HRMARS

Dehbozorgi, E. (2012). Effects of Attitude towards Language Learning and Risk-taking on EFL Students' Proficiency. International Journal of English Linguistics. 2(2): 41-48. doi:10.5539/ijel.v2n2p41

Doiz, A., Lasagabaster, D., \& Sierra, J. M. (2011). Internalization, multilingualism, and Englishmedium instruction. World Englishes, 30, 345-359. http://dx.doi.org/10.1111/j.1467971X.2011.01718.x

Firdev, K. (2007). Language attitudes of Turkish students towards the English language and its use in Turkish context. Journal of Arts and Sciences.

Fasold, R. (1984). The Sociolinguistics of Society. Oxford: Basil Blackwell

Galloway, N. (2013). Global Englishes and English language teaching (ELT)- Bridging the gap between theory and practice in a Japanese context. System, 41, 786-803.

Gardner, R. (1980). On the validity of affective variables in second language acquisition: Conceptual and statistical considerations. Language Learning, 30 (2), 255-270.

Gardner, R. (1985). Social psychology and second language learning: The role of attitude and motivation. London: Edward Arnold.

Gardner, R. (2006). The socio-educational model of second language acquisition: A research paradigm. EUROSLA Yearbook, 6, 237-260.

Gill, K. (2002). International Communication: English Language Challenges for Malaysia. Universiti Putra Malaysia Press, Serdang.

Hassan, S., \& Somayeh, H. (2013). Iranian Medical Students' Attitudes towards English Language Learning. International Research Journal of Applied and Basic Sciences. Retrieved from www.irjabs.com. 4(11), 3816-3823.

Hargender, K. (2014). Attitudes towards English language learning and language use Among secondary school students. Faculty of language and linguistic, University of Malaya.

Kachru, B. B. (1985). Standard, codification, and sociolinguistic realism: The English Language in the outer circle. In R. Quirk and H. G. Widdowson (Ed.), English in the World (pp.11-30). Cambridge: Cambridge University Press.

Kaur, P. (2014). Attitudes towards English as a lingua franca. Procedia- Social and Behavioral Sciences, 118, 214-221. http://dx.doi.org/10.1016/j.sbspro.2014.02.029

Karahan, F. (2007). Language attitudes of Turkish students towardss the English language and its use in Turkish context. Journal of Arts and Sciences, 7, 73-87.

Liu, M. (2007). Chinese Students' Motivation to Learn English at the Tertiary Level. Asian EFL Journal, 9: 126-146.

Liu, M., \& Zhao, S. (2011). Current language attitudes of mainland Chinese university students. Journal of Language Teaching and Research, (2)5, 963-968.

http://dx.doi.org/10.4304/jltr.2.5.963-968

Liu, S., \& laohawiriyanon, C. (2013). Students' attitudes towards cultural learning in the English classroom: A case study of non-English major students in a Chinese university. International Journal of English Language Education, 3(1), 28-42. Retrieved from http://dx.doi.org/10.5296/ijele.v1i3.3508

Liu, M., \& Zhang, X. (2013). An investigation of Chinese university students' foreign Language anxiety and English learning motivation. English Linguistic Research, 2(1), 1-13. Retrieved from https://doi.org/10.5430/elr.v2n1p1 
Longman. (2002). Language Attitudes. The Longman Dictionary of Applied Linguistics and Language Teaching

Lindy.W. (2006). Anxiety and speaking English as a second language. Sage Publication. 37(3), 308328

Luca, S.E. (2001). Public Speaking Fear? 21 secrets to succeed in front of any crowd. Scotland: Laurenzana Pess.

Malaysia Government Official Portal. (2012). Available: http://www.malaysia.gov.my/EN/Pages/default.aspx [Accessed: December, 2012].

Melor, Y., \& Nur, R. (2011). A Motivation and attitudes for learning English among year six students in primary rural school. Procedia Social and Behavioural Sciences, 15: 2631-2636.

Mirjana, K., \& Ana, M. (2017). Students' Attitudes towards Foreign Languages. Journal of Educational and Developmental Psychology; Vol. 7, No. 2; 2017

Nancy, K. \& Racha. (2003). A survey on the readiness of students to learn mathematics in English, B.A thesis, Universiti Kebangsaan Malaysia, Bangi, Malaysia.

Nich, C. (2005). Contributing Writer to Worldwide Learn. Occupational Outlook Handbook, 200405 Edn., Bureau of Labor Statistics, U.S.Department of Labor.

Noor, A. (2007). ESL students' perspectives on language anxiety. Unpublished Ph.D. thesis, Serdang, Universiti Putra Malaysia.

Noraini, Y., \& Noorizah, N. (1999). Breaking Down the Barriers: The Social and Cultural Interferences in Learning the English Language in Malaysia. In: Selected Proceedings of the International Conference on English is an Asian Language - the Thai Context, pp: 108-116.

Nor, A. (1995). The relationship between language learning attitudes as measured by the Nembhards's attitude toward English Scale, and the English as a second language achievement as measured by the Lower Secondary Evaluation English examination results, of form 4 Malay students from selected rural secondary schools in the district of Perak Tengah. Unpublished master's thesis, University of Houston/IAB.

Seidlhofer, B. (2004). Research perspectives on teaching English as a lingua franca. Annu.Rev. Appl. Linguistics, 24, (209-239). Retrieved from http://dx.doi.org/10.1017/S0267190504000145

Siti, S., \& Melor, Y. (2014). Attitudes and Motivation Towards Learning English Among FELDA School Students. Aust. J. Basic \& Appl. Sci., 8(5): 1-8.

Saunders, M., Lewis, P., \& Thornhill, A. (2012). Research Methods for Business Students. 6th edition, Pearson Education Limited

Samsiah, B., Kamaruzaman, J., \& Nurazila, A. (2009). Motivation and Attitude in Learning English among Uitm Students in the Northern Region of Malaysia. English Language Teaching, 2: 16-20.

Shanta, N. (2000). English, Identitv and the Malaysian Workplace. World Englishes, 19: 205-213.

Thang, S.M., and Ting, S. L., \& Nurjanah, M. J. (2011). Attitudes and motivation of Malaysian secondary students towards learning English as a second language: a case study. 3L; Language, Linguistics and Literature, The Southeast Asian Journal of English Language Studies, 17 (1). pp. 4054 
INTERNATIONAL JOURNAL OF ACADEMIC RESEARCH IN PROGRESSIVE EDUCATION AND

DEVELOPMENT

Vol. 10, No. 2, 2021, E-ISSN: 2226-6348 @ 2021 HRMARS

Thao, Q., \& Tham M. (2013). The Attitudes towards English Language Learning and Use of SelfRegulated Learning Strategies among College Non-English Majors. International Journal of Scientific and Research Publications, Volume 3, Issue 7

Yang, Y. (2010). Attitudes of Learners Toward English: A Case of Chinese College Students. The Ohio State University.

Zainol, H. (2012). EFL Students' Attitudes towards Learning English Language: The Case of Libyan Secondary School Students. Asian Social Science. 8(2): 119-134. doi:10.5539/ass. v8n2p119 